\title{
Samtalegrupper i asylmottak
}

\author{
Av Gina Caspersen og Anja Vågen Fiskum
}

\begin{abstract}
I NORGE ER DET MANGLENDE statistikk over hvor mange asylsøkere i mottak som tar sitt eget liv. Ifølge Nasjonalt senter for selvmordsforskning (NSSF) er det grunn til å anta at asylsøkere på mottak har økt risiko for posttraumatiske stressreaksjoner, komplisert sorg og andre former for psykisk uhelse. Dette er risikofaktorer en vet er knyttet til økt suicidal atferd. Problemer med integrasion, sosial fungering og evne til å nyttiggiøre seg helsehielp i et nytt vertsland, antas å oke risikoen ytterligere. Prosjektet beskrevet i denne teksten har ikke som hovedformål å forebygge selvmord, men er ment å være et lavterskeltilbud med hensikt å fremme psykisk helse hos beboere på mottak.
\end{abstract}

\section{Profesjonell frivillighet}

En onsdag ettermiddag i mars ankommer to psykologer Dikemark asylmottak. En institusionspreget bygning møter oss. På innsiden, flere rom med neonlys, dårlig vedlikehold og nedslitte møbler. En ødelagt heis, som giør det vanskelig for de eldre å manøvrere seg rundt. På et bord i annen etasje har en ansatt ved mottaket servert en kanne med kaffe og te, fruktfat og litt kjeks. På plassen utenfor sitter det mennesker fra ulike deler av verden. Området rundt er dekket med skog, med unntak av noen flere murbygninger. I den ene bygningen bor enslige menn. I den andre, familier og kvinner. I de kalde gangene henger det igjen et snev

«Samtalegrupper i asylmottak» var et treårig pilotprosjekt fra 2015 til 2017, finansiert av Extrastiftelsen. Prosjektet var organisert med prosjektleder fra Røde Kors og en referansegruppe med deltakere fra relevante fagmiljøer. Referansegruppen kvalitetssikret prosessene og bisto med veiledning og fagutvikling. I praksis gikk tiltaket ut på at frivillige psykologer, rekruttert av Røde Kors, gjennomførte gruppesamtaler med beboere på to ulike asylmottak. av lukten fra krydret mat. Vi kan høre skritt i trappen opp fra etasjen under oss. En koordinator fra mottaket tar oss imot. Han snakker dårlig norsk, men formidler at beboerne er på vei. Vi er spente og skal straks møte deltakerne til vår første samtalegruppe.

Høsten 2015 blir pilotprosjektet startet i regi av Røde Kors. 13 frivillige psykologer går inn i prosjektet for å danne samtalegrupper på asylmottak. Flere av psykogene har erfaring med gruppeterapi og/eller erfaring med å jobbe med innvandrere eller flyktninger. Gruppene blir holdt ved Dikemark asylmottak i Asker og etter hvert utvidet til Ila integreringsmottak i Oslo. Gruppene er satt sammen ut ifra språktilhørighet. Dette for å kunne bruke én tolk per gruppe. I prosjektperioden blir det til sammen giennomført tolv gruppesamlinger. Gruppene møtes annenhver uke, med to parallelle grupper hver onsdag kveld. Dette blir etter hvert endret til ukentlige samtaler over $5^{-8}$ uker, for bedre kontinuitet i prosessen. Antall deltakere i gruppene varierer fra 1-16 deltakere. Normalt er det 6-8 deltakere i hver gruppe.

For å sette sammen gruppene blir det holdt individuelle forsamtaler. Dette er nyttig for å kartlegge hvilke beboere som kan nyttiggiøre seg av gruppetilbudet, og for å vite hvem som ønsker å delta i prosjektet etter at tilstrekkelig informasion er blitt gitt. Forsamtalene blir også brukt for å kunne utforske beboernes behov og onsker, samt være en arena for å ta opp eventuelle spørsmål. Noen av beboerne vi møter har vært i Norge i mange år, andre kom i forrige uke. Noen venter på å få søknaden om opphold behandlet av UDI. Andre har fått oppholdstillatelse, men venter på tildeling av personnummer og bostedskommune. På mottaket bor det også mennesker som har fått endelig avslag.

\section{En felles forståelse av vansker og behov}

Vi ser at det er behov for hielp, og hodet er fullt av tanker og ideer, men tidlig blir vi møtt med utfordringer. Som psykologer utdannet i Norden har vi vestlige tanker om at det å prate med noen om sine vansker, skal virke 


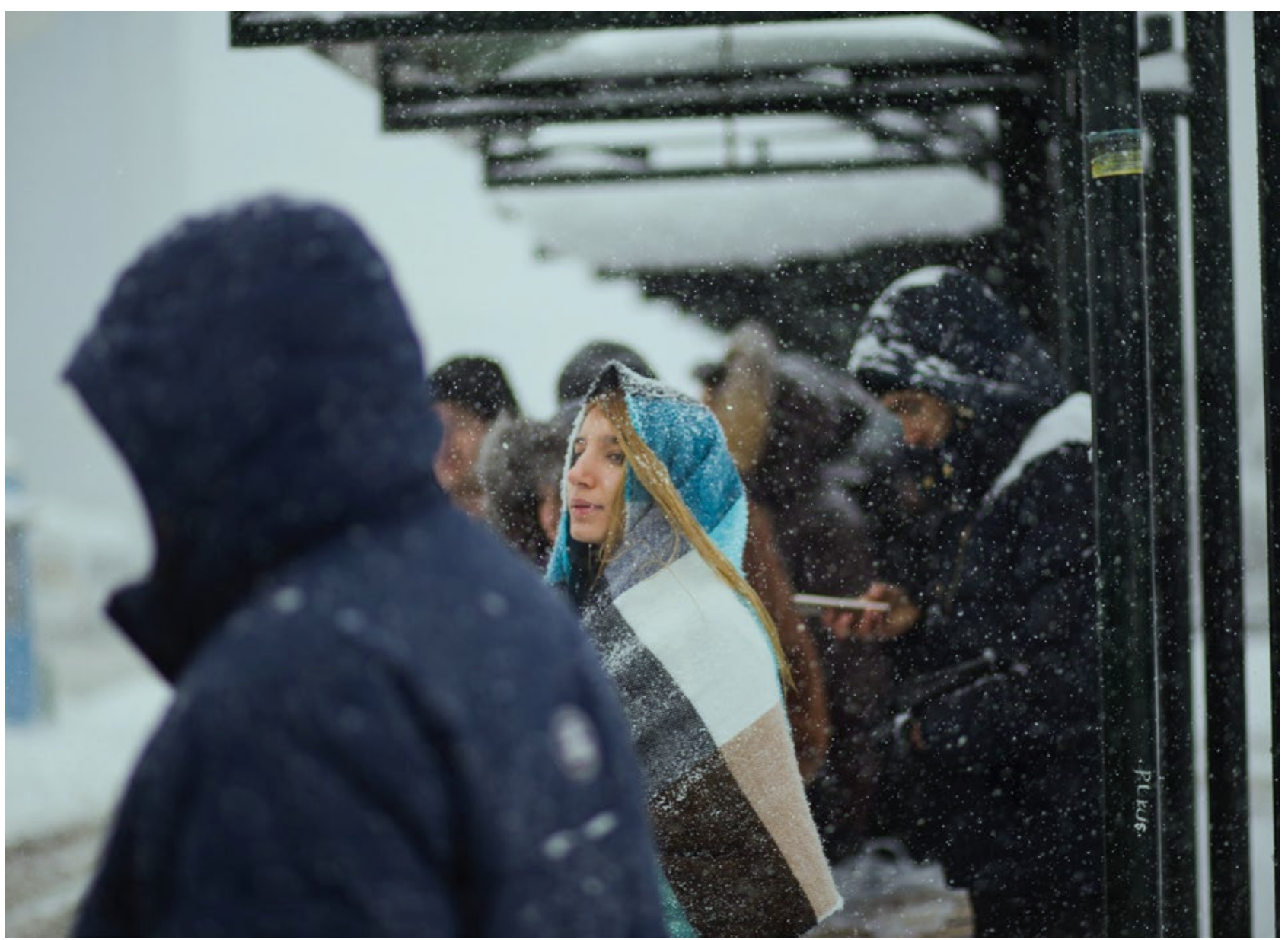

lindrende. Mange av beboerne kommer fra mer kollektivistiske kulturer der religion er en stor del av deres liv. Konseptet med å snakke om sine innerste tanker og følelser er for mange ukjent, og for noen er det også uakseptabelt å snakke om sine vansker utenfor familien. Mange har en annen forståelse av mestring og fokus på å være sterk. For noen er også bønn en stor del av deres mestring i hverdagen. Det blir viktig for oss å finne en balanse mellom hva deltakerne opplever som nyttig og hva vi har med oss av psykologisk kompetanse. Kart og terreng må passe sammen.

Vi ønsker å hielpe, giøre en forskjell. Bidra til at beboerne kan finne mening i en meningsløs tilværelse. Rammene for et normalt psykologarbeid er mangelfull, og vi skal heller ikke fungere som miljøterapeuter. Det kan til tider være vanskelig å se klart for seg hva vi kan bidra med. Mange av beboerne har med seg vonde opplevelser både fra situasionen i hjemlandet og fra flukt. For å skape en rammemodell for gruppesamtalene tar vi utgangspunkt i egen fagbakgrunn og fokuserer på beboernes indre vansker, som f.eks. stress, uro, angst, depresjon og apati. Denne problemforståelsen samsvarer ikke alltid med beboernes opplevelse. Det kommer tydelig frem at den isolerte tilværelsen på mottaket er en stor påkjenning for mange, og flere av beboerne plasserer flere av sine vansker i de ytre omgivelsene. Beboerne uttrykker frustrasion over forholdene på mottaket og forteller om skitne og ødelagte madrasser, dårlig standard og hygiene, samt ødelagte gienstander. I tillegg til praktiske og materielle problemer, forteller de om manglende helsetilbud og vansker med språk. De føler seg isolerte og savner familien. Mange av beboerne knytter også sine problemer til somatisk sykdom som tannverk, vondt i magen eller hodet. Vanskeligst av alt er kanskje det å leve i en svært usikker og uforutsigbar Vi onsker å hielpe,
giore en forskjell.
Bidra til at beboerne
kan finne mening i en
meningslos tilvarelse. tilværelse i påvente av svar på søknad om oppholdstillatelse.

Flere ganger underveis kjenner vi på et onske om å bidra med mer konkret og praktisk hielp. Beboerne ønsker seg internett-tilgang, hjelp til å få skrudd ned sentralfyringen slik at det ikke er så varmt om natten, og hjelp til få hengt opp gardiner for å skjerme mot solen når den står på som verst. Juridisk hielp til å forstå søknadsprosessen og betale for legetimer og kollektivtilbud for de som onsker å ta en pause fra 
mottakets fierne beliggenhet er andre onsker. Beboerne opplever at de mangler alt. De mangler håp, vinterklær og varme. De mangler søvn, informasion og forutsigbarhet. Beboerne venter på et liv.

\section{Gruppesamtalenes innhold}

I en hverdag med lite struktur og manglende aktiviteter er det kanskje nettopp dette som er med på å skape nysgierrighet og interesse for tilbudet om samtalegrupper. Da er det tross alt noe som skjer. Men samtaler? Om hva? Både ved oppstart og underveis blir det viktig å avklare og repetere forventninger og hva vi som psykologer kan bidra med, og ikke - at vi ikke har noen form for konkret påvirkning på forholdene på mottaket, eller på søknad om oppholdstillatelse. Men vi kan være der, lytte og skape en møteplass med fokus på å styrke deres evner til å mestre hverdagen.

Tema for gruppesamtalene blir valgt med utgangspunkt i etablerte behandlingsmanualer, blant annet utarbeidet ved Modum Bad og Helsesenteret for papirløse migranter. Metoden fokuserer på stabilisering og regulering, samt bidra til forståelse og innsikt - hjelp til å forstå at reaksjoner etter alvorlige hendelser kan være følelsesmessige, kognitive og påvirke atferd. Deltakerne uttrykker at det å få mer kunnskap om hva som er normale reaksjoner på ekstreme erfaringer oppleves som nyttig.
Målet er å kunne skape mening og kontroll for at beboerne skal kunne mestre hverdagen bedre. Tema for samtalene blir bestemt sammen med gruppen allerede i forste samling, slik at vi som psykologer kan tilpasse samlingene etter gruppens behov og onsker. Vi onsker å ha en rød tråd giennom hele forløpet, og to ulike psykologiske forklaringsmodeller blir derfor brukt på tvers av tema. I tillegg til dette benytter vi bevisst ikke-verbal kommunikasjon som musikk, tegning og fysiske øvelser.

Fjerde gruppesamling. Etter felles velkomst setter vi oss i en sirkel rundt et brennende stearinlys. Lyset symboliserer vår felles taushetsplikt. Noen av deltakerne har allerede lukket øynene, i påvente av den faste reguleringsøvelsen som skal symbolisere vår felles overgang fra hver enkeltes hverdag og inn i gruppen. Etter øvelsen har en deltaker kommentar på tema fra forrige gang. Han vil gierne dele tanker med gruppen. Flere har kommentarer. Andre sitter lyttende. Tema for dagen presenteres og knyttes opp mot hverdagslige utfordringer hos deltakerne.

Pause. Vi spiser noe sammen. Noen fraser utveksles på arabisk. Vi som psykologer har også lært oss noen ord, og får stadig vennlige rettelser på uttale av deltakerne. Bruk av kroppsspråk og lytting til musikk som en av

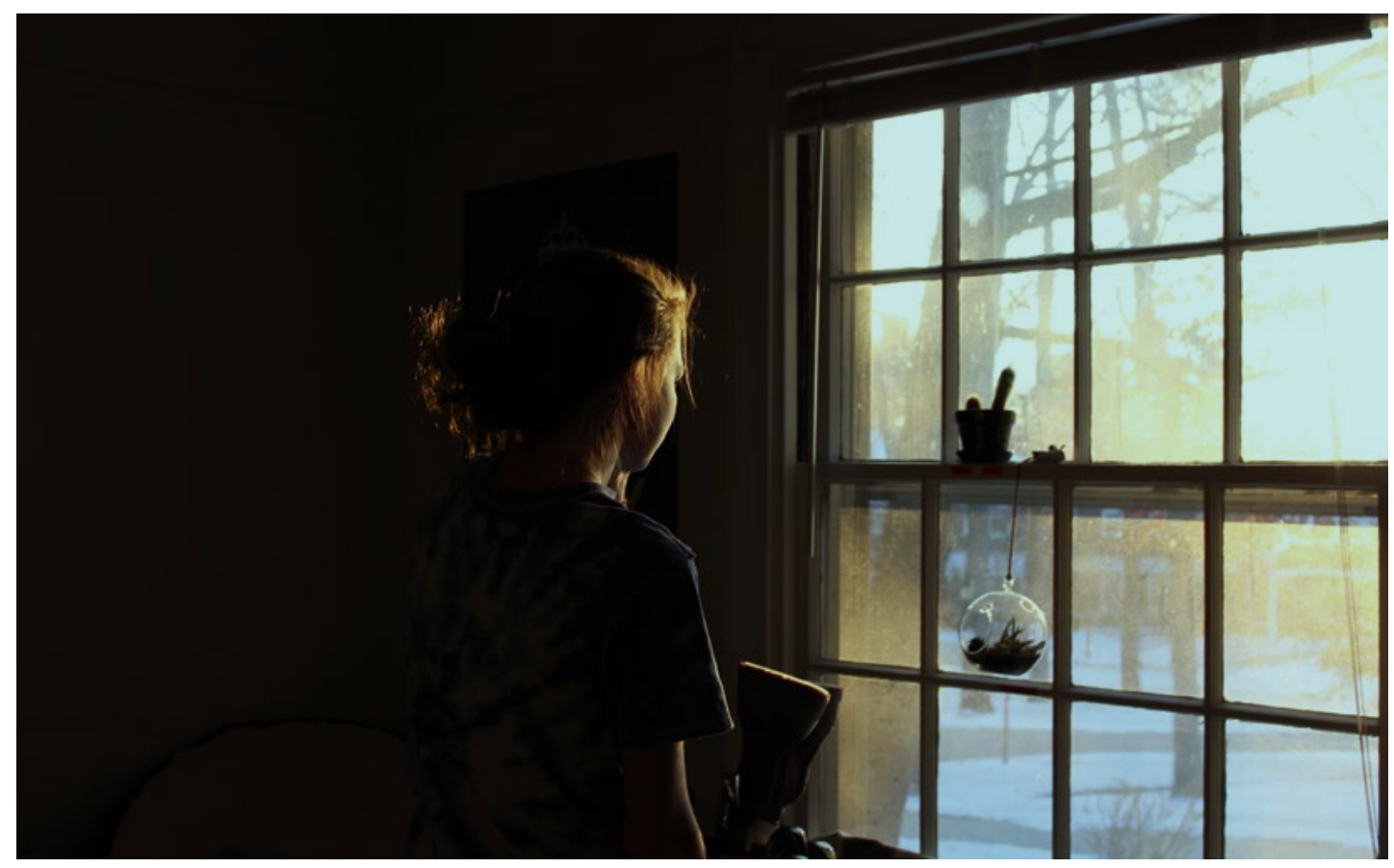




\section{Fleksibilitet, nysgierrighet og ydmykhet \\ i mote med mennesker hvis kultur og livssituasjon på mange måter er så ulik vår egen, har vært essensielt.}

deltakerne har med er også med på å lage en løsere stemning, før vi skal tilbake til tyngre tematikk.

Pausen er over. Vi giennomgår resten av tema for dagen og diskuterer hvordan følelser og stress kan henge sammen med somatikk. Vi informerer om tema for neste gang. Avslutningsvis reiser vi oss opp og holder hender. Sammen utgiør vi en kraftsirkel. Vi lukker øynene, mens tekst leses opp og vi avslutter med å onske hverandre gode tanker til neste gang. Dette blir avsluttende samtale. Etter onske fra deltakerne skal vi til Oslo. Vi skal på museum og spise falafel. Noen gleder seg, mens andre er spente og usikre på om de kan få det til.

\section{Gode erfaringer og stadig behov}

Avslutning. Gruppesamtalene oppsummeres sammen med deltakerne. Erfaringer og opplevelser deles. Noen forteller om en positiv endring. Flere uttrykker å ha fått en større forståelse av sine egne og andres reaksjoner. De sover bedre og er mindre stresset. Andre uttrykker vemod over at gruppetilbudet er over og er bekymret for et tomrom i hverdagen. Vi uttrykker alle stor takknemlighet over å ha fått deltatt. I en hverdag som ellers kan kjennes lang, håpløs og kaotisk, har vi sammen skapt et felles rom hvor tanker og følelser kan deles med hverandre.

Det er mange faktorer som har bidratt til at gruppene har fungert godt. Et godt samarbeid med mottakets koordinator har vært svært viktig, blant annet for å minne deltakerne på tidspunkt for gruppesamtalene og tilrettelegging av praktiske forhold. Vi har erfart at bruk av samme tolk både i de individuelle forsamtalene og giennom alle gruppesamtalene er svært nyttig. Dette bidrar til å skape ytterligere trygghet og tillit i gruppen, og en økt kontinuitet i oversettingen. At vi kommer som frivillige fra en organisasjon oppleves å inngi tillit til at vi ønsker å hjelpe. I møte med deltakerne er det viktig for oss som psykologer å ha en god faglig forankret forståelse. Et stikkord for gruppesamtalene har vært normalpsykologi, fremfor sykeliggiøring og diagnostisering. Vi tar med oss teoretisk kunnskap inn i møte med deltakerne, men en holdning preget av medmenneskelighet har vært vel så viktig. Fleksibilitet, nysgierrighet og ydmykhet i møte med mennesker hvis kultur og livssituasjon på mange måter er så ulik vår egen, har vært essensielt.

Til tross for positive tilbakemeldinger fra mange av gruppedeltakerne, er det slik at bare en liten del av beboerne faktisk har deltatt i samtalegruppene. Det bor mange mennesker på asylmottaket, og kanskje er de som trenger det mest fortsatt inne på rommene sine. Vi opplever at det fremdeles er et stort behov for ulike former for hielp på asylmottaket. Det er ikke slik at vår modell nødvendigvis er den riktige å arbeide etter. Vi tror allikevel at elementer av dette kan virke forebyggende mot beboernes psykiske plager og dermed også mulig suicidal atferd. Vi vet at det å få hjelp med søvnvansker, økt forståelse av egne og andres helseplager og det å finne strategier for å regulere stress er forbundet med færre psykiske plager. Opplevelsen av sosial verdi og tilhørighet, det å bli møtt med vennlighet, samt det å bli lyttet til når en har vanskelige tanker og følelser kan også bidra til en bedre psykisk helse.

Vi mener derfor at et arbeid rettet mot dette bør få en større plass på asylmottak.

For å lese mer om de samlede erfaringene fra prosiektet se Røde Kors sin sluttrapport for «Samtalegrupper i mottak» skrevet av Buvik, K. og Bang Hansen, M. (2017) og Buvik, K. og Baklien, B. (2017). Mellom idealer og realiteter på Dikemark asylmottak. Norsk sosiologisk tidsskrift, 5, 347-364.

Forfatterne er psykologer og frivillige i Røde Kors.

\section{REFERANSER}

NRK information. (Artikkelen «de usynlige dødsfallene» 23.09.2018) https://www.nrk.no/norge/xl/de-usynlige-dodsfallene-1.14108792? fbclid=IwAR3XUisCRDIHpnaJAPIV1Id7BZZa3YYM8l2e1IaYEYwIzvFghAYFZenSqwFo

Universitetet i Oslo. (Prosjektet «Suicidal behaviour and health care - differences between refugees, immigrants and natives?» 20.12. 2017). https://www.med.uio.no/klinmed/forskning/ sentre/nssf/aktuelt/aktuelle-saker/2017/risikofaktorer-for-selvmord-blant-flyktninger-i-no.htm 